\title{
EDITORIAL: \\ ON OPEN ACCESS PUBLISHING
}

In the wake of recent revelations about labor abuse, unethical conduct, and financial mismanagement at HAU: The Journal of Ethnographic Theory (Former HAU Staff 7 2018; Former and Current HAU Staff 2018; Graeber 2018), and the ensuing reactions and critiques shared under \#hautalk (see Agro 2018), much has been written about the problems of scholarly journals and open access publishing. Although it seems to be the prevailing opinion that open access publishing and perhaps even the relative freedom of academic publishing from commercial interests are good things in their own right, the opposite claims have also been voiced: that open access publishing lacks the established structures and funding models of mainstream scholarly press (Kalb 2018, cf. Baird Jackson 2018; Coelho 2018; Gershon 2018; Pandian 2018; Weiss, Paxson and Nelson 2018); and that open access publishing too often reproduces elitist and exclusivist power structures that privilege 'big names' and 'top schools' while marginalizing scholars who are often already sidelined within academia: indigenous scholars, scholars of color, LGBT scholars, precarious scholars, and scholars trained and working outside of the North Atlantic (Todd 2018; West 2018; Dunn 2018). One possible conclusion from these important critiques is that what took place at $H A U$ was indicative of a flaw in the make-up of open access publishing more generally.

Like so many others, we at Suomen Antropologi: Journal of the Finnish Anthropological Society have been alarmed by the HAU scandal. And like many others, we see \#hautalk as an opportunity to criticize, rethink, and transform professional norms in social and cultural anthropology (Ivasiuc et al. 2018; Todd 2018; West 2018). Furthermore, as an open access anthropology journal, we see it as imperative to explicate our own operating procedures, governing structures and financial model (see also the statement by the editors at Cultural Anthropology [Weiss, Paxson and Nelson 2018]). In doing so, we strive to illustrate one model of open access publishing that, in spirit and in letter, is committed to fairness, collaboration, transparency, and high quality intellectual exchange.

Suomen Antropologi: Journal of the Finnish Anthropological Society is, like so many other journals, run by a scholarly society. Its Editor-in-Chief is nominated by the society for two years, renewable once; its publishing and review policies have been decided by the society. Even the decision to replace the printed journal with an electronic open access publication was made after consulting the society's membership in 2011. The substantial majority of 68 per cent of the survey takers were willing to support an 
open-access online journal, even if it meant they would not receive a printed copy as their membership benefit.

The Finnish Anthropological Society funds the journal. The society's annual meeting decided that the journal should not be a restricted access publication, only available to members and subscribers, but openly accessible to as wide a reading public as possible. The journal collects no subscription fees, no article processing fees, and receives no payments from online databases. Currently, the publishing of the journal is possible only through the membership fees of members of the Finnish Anthropological Society and an annual publishing grant from the Finnish state.

The journal uses an open-source publishing platform called Open Journal Systems (OJS). The hierarchical architecture of the OJS platform was recently discussed by Ilana Gershon (2018), who rightly points out that it encourages a particular type of pyramid organisation through the way it allocates roles and responsibilities. Gershon makes a valid point, although as a smaller, mostly face-to-face organization, the working culture of Suomen Antropologi is built outside the OJS platform. But OJS also has benefits for a small journal like Suomen Antropologi: for instance, it archives the review processes and editorial decisions in a way that can be accessed posthumously, even brought under review if necessary. This is a marked improvement to, say, an editor archiving such matter in his/her private e-mail. Moreover, use of the platform is supervised and supported by a national umbrella organisation called The Federation of Finnish Learned Societies, which also controls the user account and rights and the abovementioned state grants. Ultimately, the Federation of Learned Societies recognizes the Finnish Anthropological Society's authority over the journal editor, thereby ensuring that control of the publishing platform remains with the research community rather than a single individual.

It is another significant benefit of the OJS platform that the journal does not have to pay for its use. This allows the journal to pay modest wages to its Editorial Secretary, Language Editor, and Typesetter. In a good year, the Society has been able to pay the Editor-in-Chief an honorarium for his/her services. This may not sound like a particularly lucrative publishing model. In many ways, however, it is precisely what made the decision to go open access easy for the journal; it had always been an "indie" journal, which among other things means that it has never generated much revenue. At best, the journal's meagre deal with an online database earned it 300USD a year. However, even more importantly, the decision to provide the journal's contents free of charge was motivated by a desire to contribute to a paradigm shift in academic publishing. Since 2015, the journal has been part of project Kotilava (acronym for the Finnish words 'Finnish academic 
journals towards immediate Open Access', see website Kotilava 2016). The project has brought together journals, university libraries, the Ministry of Education and Culture and other civil servants to create a national open access funding consortium whose purpose is to make publicly funded research results available to the public.

The calculation behind the project is simple enough: currently institutions of higher education and various funding bodies are paying Article Processing Fees that, even in a field like anthropology, can easily rise to 2,000€-3,000€ per article. The universities in particular are willing to put up with this because a large part of the funding is based on their quantifiable research outputs. In Finland, for example, the monetary value of an article is based on a national Publication Forum (2017) that ranks peer-reviewed publications into three categories: a university gets roughly $4,000 €$ for an article published in a "Level 1" journal, 12,000€ for a "Level 2" article, and considerably more for the highest category. The project seeks to establish a new model for redistributing public funds that would make open access publishing an obvious route.

This system, which currently is likely to be established by 2020, is far from ideal. It turns research-based knowledge into a fictitious commodity with its own scales and measures. What is worse, it is currently promoted by bureaucrats who see 'openness' as a goal achieved with carrot and stick, and 'voluntarily' open access actors as 'freaks' with unfathomable motivations. But despite its neoliberal realization, it is also based on worthy ideals: public accessibility of research and maintaining the control of Finland's scholarly journals in the hands of the research communities rather than handing them over to international publishing companies.

Highlighting the particularity of this 'Nordic' open access model is also a good way of reminding everyone what a mixed bag 'open access' is at this point in time. You can find immediate open access, embargoed open access, open access funded by author fees, open access funding corporations, institutionally funded open access, open access as a common good, open access as an auditing scale, and so on and so forth. The problems of academic publishing will not be overcome overnight simply by providing wider access to research results. But it is a start.

It is too early to tell whether or not the decision to go open access has had an effect on the kind of anthropology published in Suomen Antropologi: Journal of the Finnish Anthropological Society. In his editorial to the journal's first open access issue in 2016, the Editor-in-Chief, Timo Kallinen, who oversaw the transition to open access publishing, pointed out that reaching as wide an audience as possible has been one of the journal's main goals since the publication of its first issue in 1976. Obviously, the journal can 
only publish texts submitted to it for publication but, judging by what has been published in Suomen Antropologi: Journal of the Finnish Anthropological Society, we have managed to reach readers and writers ever further from Finland and the disciplinary 'core'. Over the past two years, in addition to Finland, the journal has published authors affiliated with universities in Australia, Chile, Denmark, France, Greece, Norway, South Africa, Spain, Sweden, US, and UK. Perhaps more importantly, JFAS has been able to publish material on a wide scale ranging from ritual studies to hip hop anthropology or projects that seek to establish common ground: for example, between anthropologists and artists.

As Anand Pandian (2018) argued in his own reflection on open access in the aftermath of the HAU scandal, now is not the time to resign ourselves to paywalls or other, often informal walls that create and reproduce professional divides. In a similar vein, we feel that now is precisely the time to double down on open access publishing and to imagine and implement 'openness' and 'access' well beyond the question of 'to paywall or not to paywall'. To this end, we invite conversation and reflection on Suomen Antropologis ongoing experiment in open access publishing. Furthermore, we look forward to collaborating with, supporting, and witnessing peer projects in equitable open access publishing that seek not only to make research globally accessible but also to expand the horizons of scholarship in anthropology.

\section{REFERENCES}

Agro, Hilary 2018. Twitter Thread. Twitter June 13.

https://twitter.com/hilaryagro/status/1006995504205459456. <accessed 24 July 2018>

Baird Jackson, Jason 2018. Community-based Open Access, Fast and Slow. \#Hautalk. AllegraLab June 20.

http://allegralaboratory.net/community-based-open-access-fast-and-slowhautalk/. <accessed 24 July 2018>

Coelho, Caio 2018. HAU is Dead, Long Live OA Initiatives. Anthro\{dendum\} June 13.

https://anthrodendum.org/2018/06/13/hau-is-dead-long-live-oa-initiatives/. <accessed 24 July 2018>

Dunn, Elizabeth Cullen 2018. The Problem with Assholes. Public Anthropologist June 20.

http://publicanthropologist.cmi.no/2018/06/20/the-problem-with-assholes/. $<$ accessed 24 July 2018> 
Former and Current HAU Staff 2018. Former and Current HAU Staff Letter. HAU Staff Letter Website June 14. https://haustaffletter.wordpress.com/2018/06/14/ june-14th-2018/. <accessed 24 July 2018>

Former HAU Staff 7 2018. Guest Post: An Open Letter From the Former HAU Staff 7. Footnotes June 13. https://footnotesblog.com/2018/06/13/guest-post-anopen-letter-from-the-former-hau-staff-7/. <accessed 24 July 2018>

Gershon, Ilana 2018. Pyramid Scheme. \#Hautalk. AllegraLab June 19. http://allegralaboratory.net/pyramid-scheme-hautalk/. <accessed 24 July 2018>

Graeber, David 2018. HAU Apology. David Graeber Industries. https://davidgraeber.industries/sundries/hau-apology/. <accessed 24 July 2018>

Ivasiuc, Ana, Mariya Ivancheva, Lara McKenzie and Dan Hirslund on behalf of the PrecAnthro Collective 2018. \#PrecAnthro. Let's Talk About Unionization. \#Hautalk. AllegraLab June 21. http://allegralaboratory.net/precanthro-lets-talkabout-unionisation-hautalk/. <accessed 24 July 201>

Kalb, Don 2018. HAU not: For David Graeber and the Anthropological Precariate. FocaalBlog June 26. http://www.focaalblog.com/2018/06/26/don-kalb-hau-notfor-david-graeber-and-the-anthropological-precariate/. <accessed 24 July 2018>

Kotilava 2016. Kotilava—Finnish Academic Journals Towards Immediate Open Access. Kotilava Website August 19. http://www.kotilava.fi/19-elokuu-2016-1247/ kotilava-\%E2\%80\%93-finnish-academic-journals-towards-immediate-openaccess. <accessed 24 July 2018>

Pandian, Anand 2018. Open Access, Open Minds. Disptaches, Cultural Anthropology Website June 15. https://culanth.org/fieldsights/1455-open-accessopen-minds. <accessed 24 July 2018>

Publication Forum 2017. Evaluations. Publication Forum Website October 6. http://www.julkaisufoorumi.fi/en/evaluations. <accessed 24 July 2017>

Todd, Zoe 2018. The Decolonial Turn 2.0: The Reckoning. Anthro\{dendum\} June 15. https://anthrodendum.org/2018/06/15/the-decolonial-turn-2-0-thereckoning/. <accessed 24 July 2018>

Weiss, Brad, Heather Paxson and Christopher Nelson 2018. How Cultural Anthropology Operates. From the Editorial Office, Cultural Anthropology Website June 18. https://culanth.org/fieldsights/1456-how-cultural-anthropology-operates. <accessed 24 July 2018>

West, Paige 2018. Twitter Thread. Twitter June 12.

https://twitter.com/PaigeWestNYC/status/1006367616917573632. <accessed 24 July 2017>

ANDREW GRAAN, Editor

ELINA HARTIKAINEN, Editor

TIMO KALLINEN, Emeritus Editor-in-Chief

VILLE LAAKKONEN, Assistant Editor

TUOMAS TAMMISTO, Editorial Secretary

PEKKA TUOMINEN, Review Editor

MATTI ERÄSAARI, Editor-in-Chief 